ニュース

\title{
7.13 新潟豪雨に伴う斜面災害調査報告
}

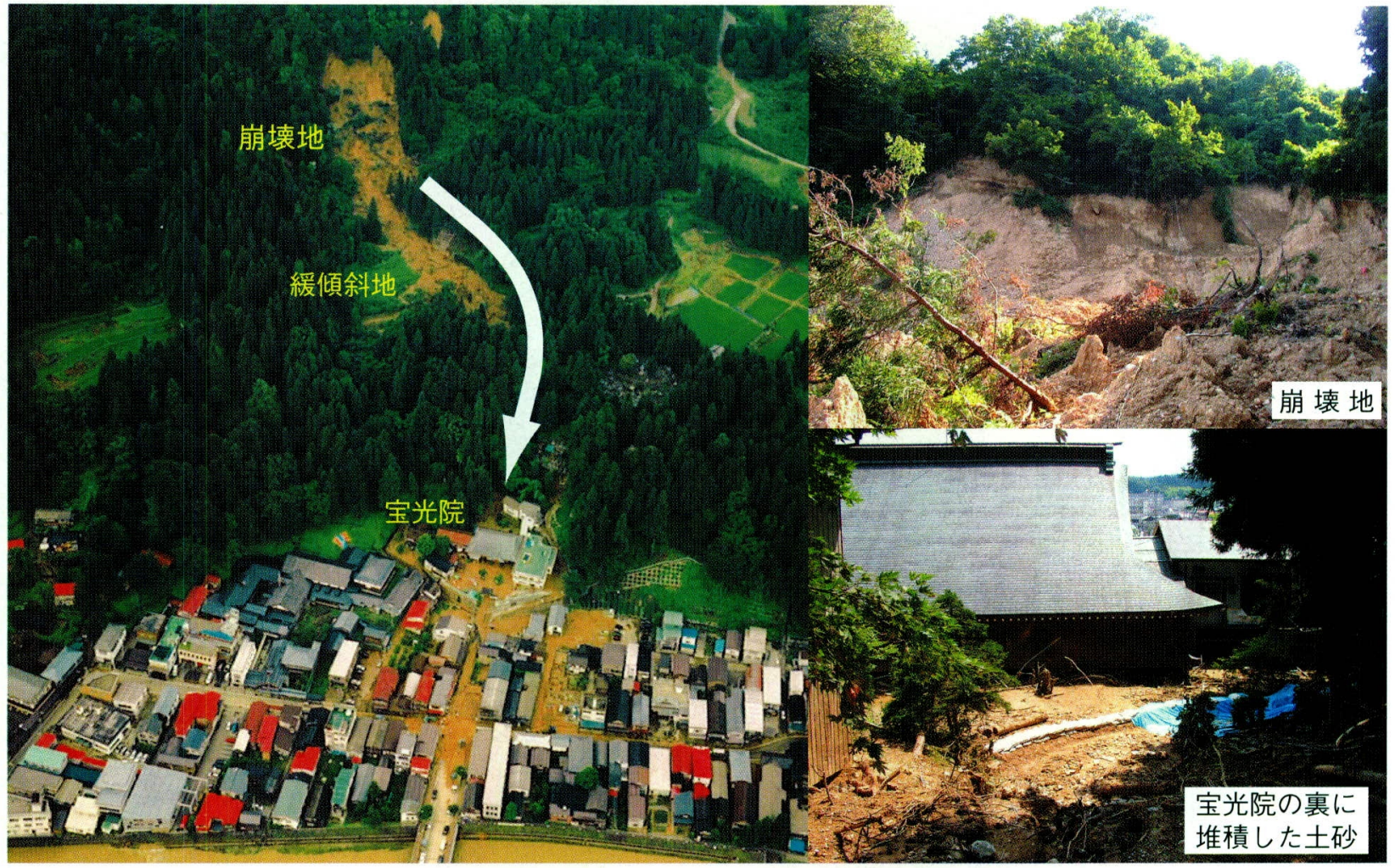

【新潟県栃尾市大町】梅雨前線の活動に伴う 7 月13日の豪雨により, 崩壊と土石流が発生。土砂の大部分は崩壊地直下の緩傾斜地に堆積。 一部は流下し宝光院の本堂を直撃。(写真提供：左は朝日航洋(侏), 右 2 枚は新潟大学)

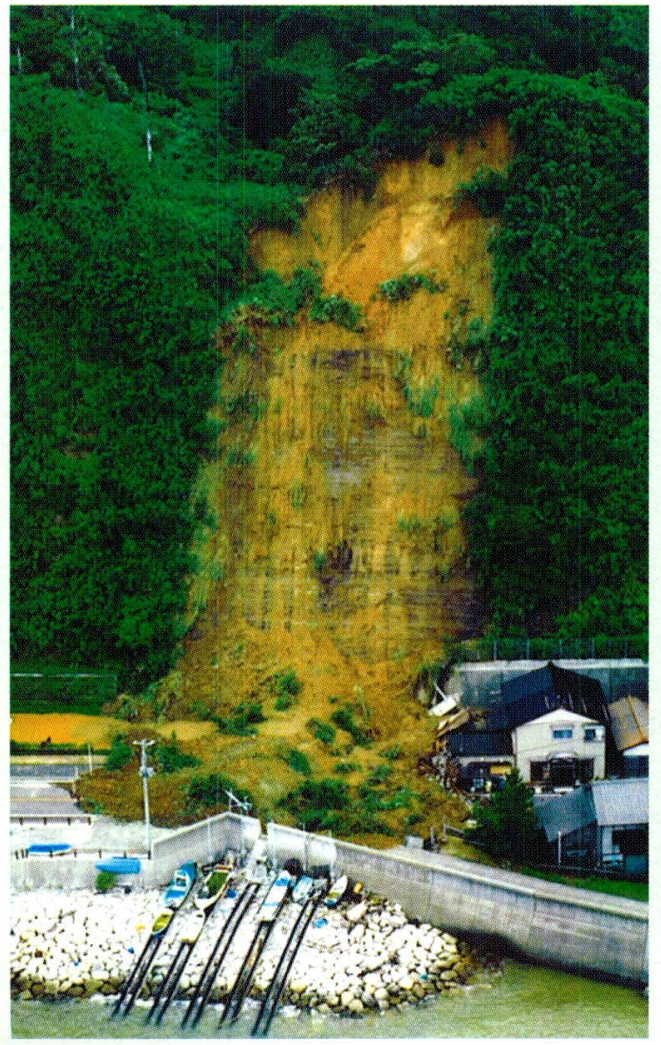

【新潟県寺泊町山田】沿岸部の急崖で表層崩壊が発生。 崩土により国道が通行止め。(写真提供：朝日航洋(侏))

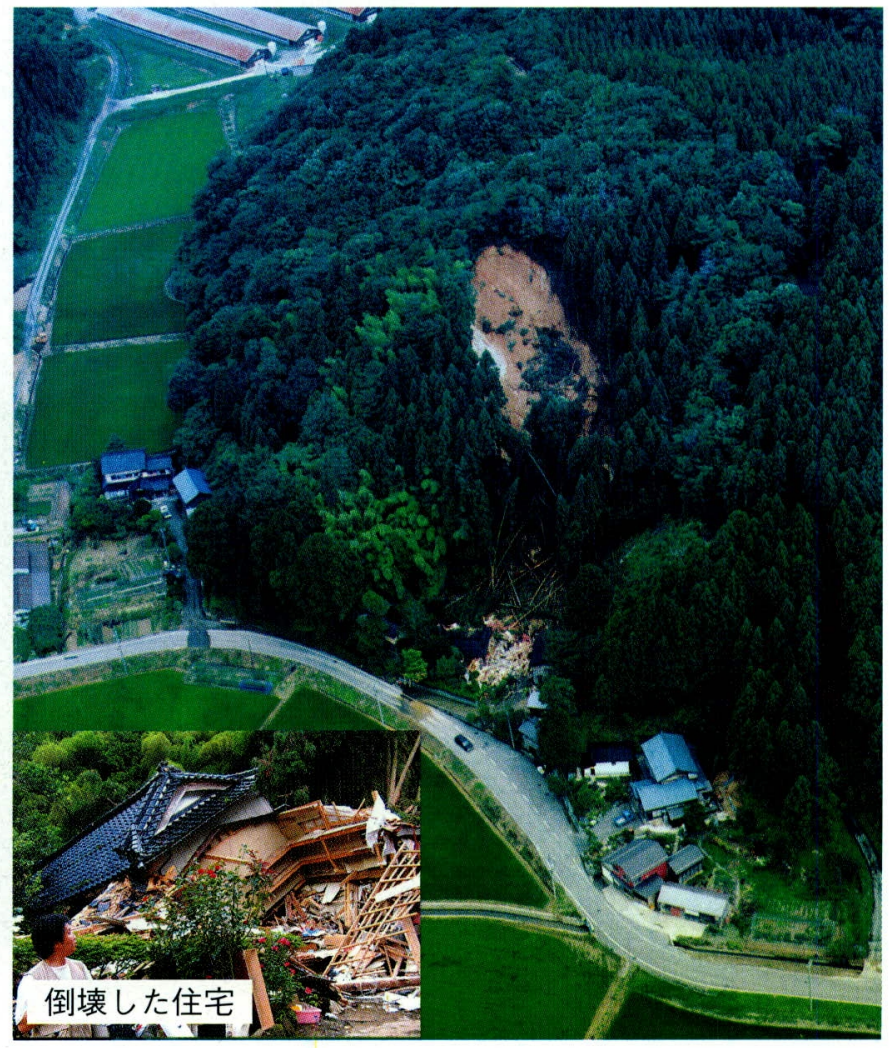

【新潟県出雲崎町中山】地すべり性崩壊が発生し, 流下した土砂により 住宅が倒壊（1 名が犠牲）。シルト岩の層理面に沿って崩壊が発生。 (写真提供：アジア航測株), 左下は新潟大学) (本文80頁参照) 


$$
\text { 二 ユース }
$$

\section{平成16年台風10号による徳島県那賀川上流域で発生した土砂災害の緊急調査報告}
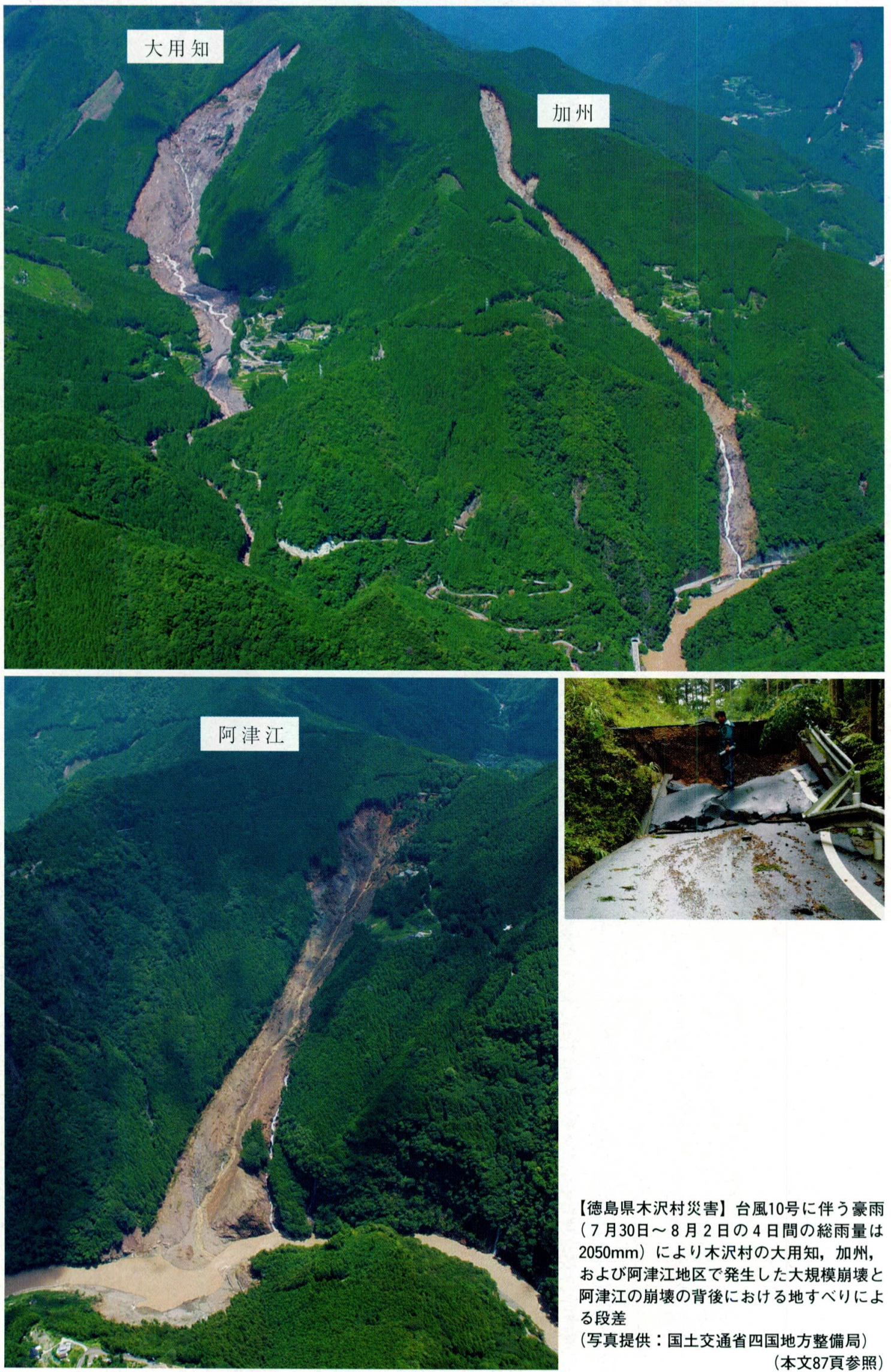

【徳島県木沢村災害】台風10号に伴う豪雨 ( 7 月30日〜 8 月 2 日の 4 日間の総雨量は 2050mm）により木沢村の大用知，加州， および阿津江地区で発生した大規模崩壊と 阿津江の崩壊の背後における地すべりによ る段差

（写真提供：国土交通省四国地方整備局） 
平成16年 7 月福井豪雨災害における斜面災害調查報告

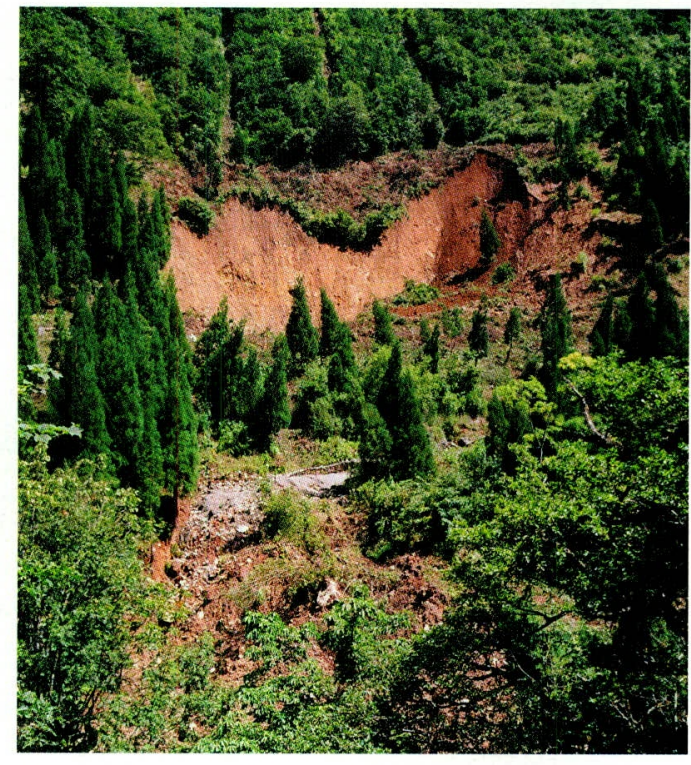

【福井県大野市下打波】活発な梅雨前線が北陸地方を南下したこと に伴う集中豪雨（平成16年 7 月17日夜〜18日）により地すべり災 害（幅75m, 斜面長 $175 \mathrm{~m}$ ) が発生。林道が寸断され, 末端部の押 し出しにより渓床部が閉塞・湛水（写真提供：国土防災技術(侏)。

\section{特集：地すべりと植生}

口基岩の状態に影響される根系の崩壊防止機能

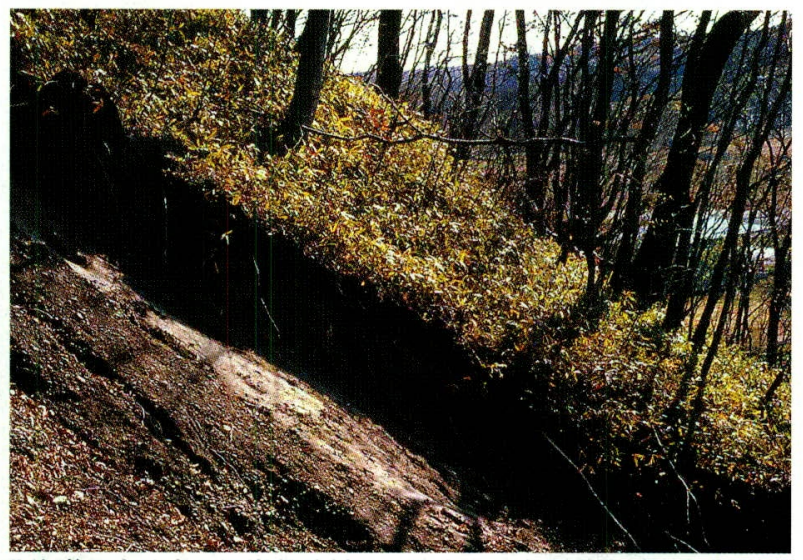

北海道日高地方の河岸段丘斜面で発生した表層崩壊（写真上左）。 植生は広葉樹の二次林で, 林床にミヤコザサが生育している。数 十cmほどの薄い土壃層の下にある泥岩層は亀裂が未発達で, 樹木 の根は泥岩層に侵入することができない。したがって, 根系が土 壤層を斜面上に保持する力が弱く, 表層崩壊が発生したと考えら れる。このように, 根系の持つ崩壊防止機能は基岩の状態に大き く左右される。(阿部和時提供)

樹木根系を含んだ試験土層と原位置一面せん断試験（写真右上下）。 根系を含んだ土のせん断抵抗力を測定するため, 対象とする樹木 (スギ)を中心に, 縦横 $1.0 \mathrm{~m}$, 高さ $0.5 \mathrm{~m}$ の試験土層を掘り出したと ころ。試験土層底面と地盤との境界がせん断面となる(上)。試験 土層の側面と上面を鉄製の枠で覆った後, 鉄道レールを利用して 鉛直荷重を与え, 油圧ジャッキでせん断試験を行っている状況(下)。 試験中はせん断応力と变位量を測定し, 試験終了後は土層を壊し てせん断面に生育していた根の直径を計測する。(阿部和時提供)

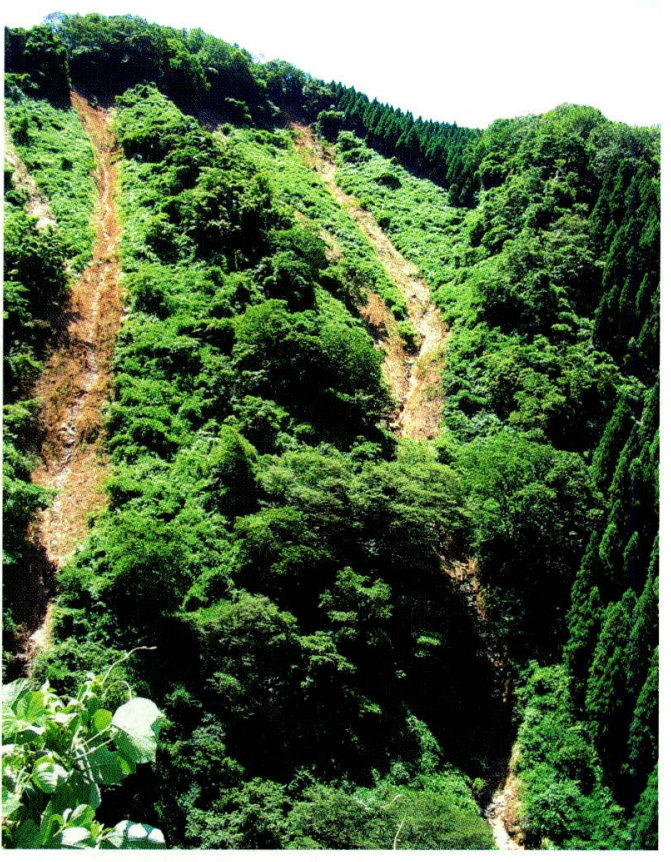

【福井市浄教寺】

（写真提供：森林総合研究所）（本文85頁参照）

口樹木根系を含んだ原位置一面せん断試験
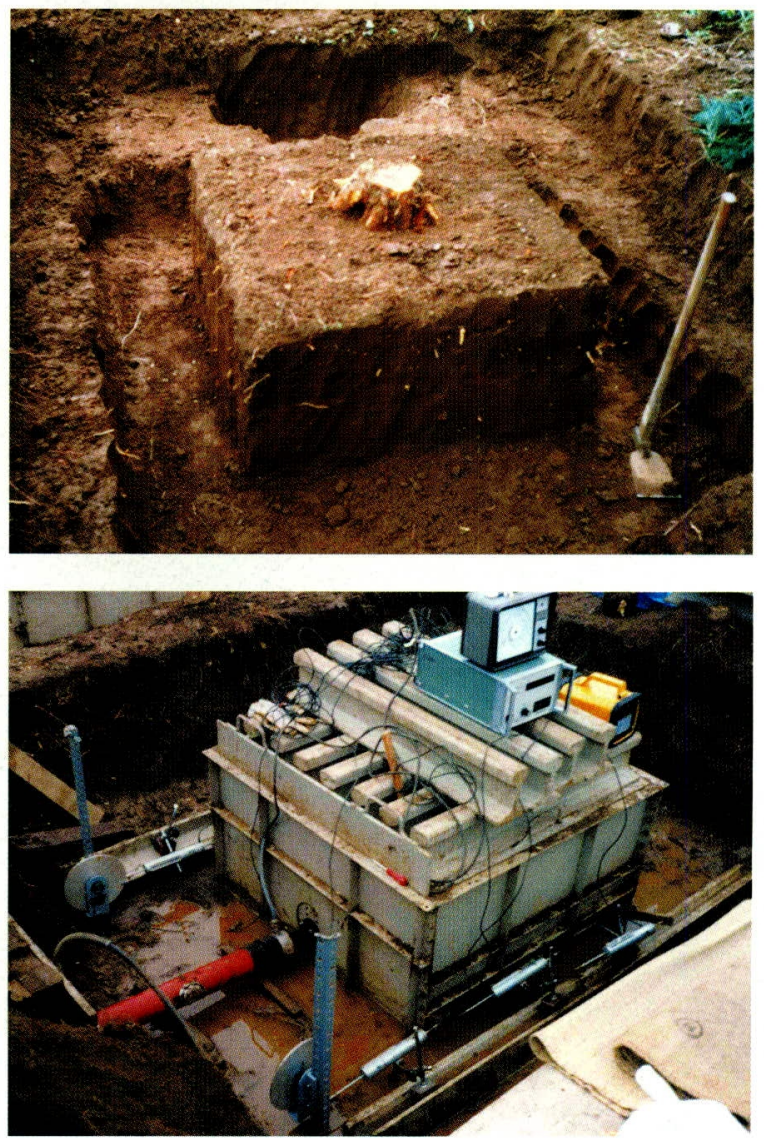


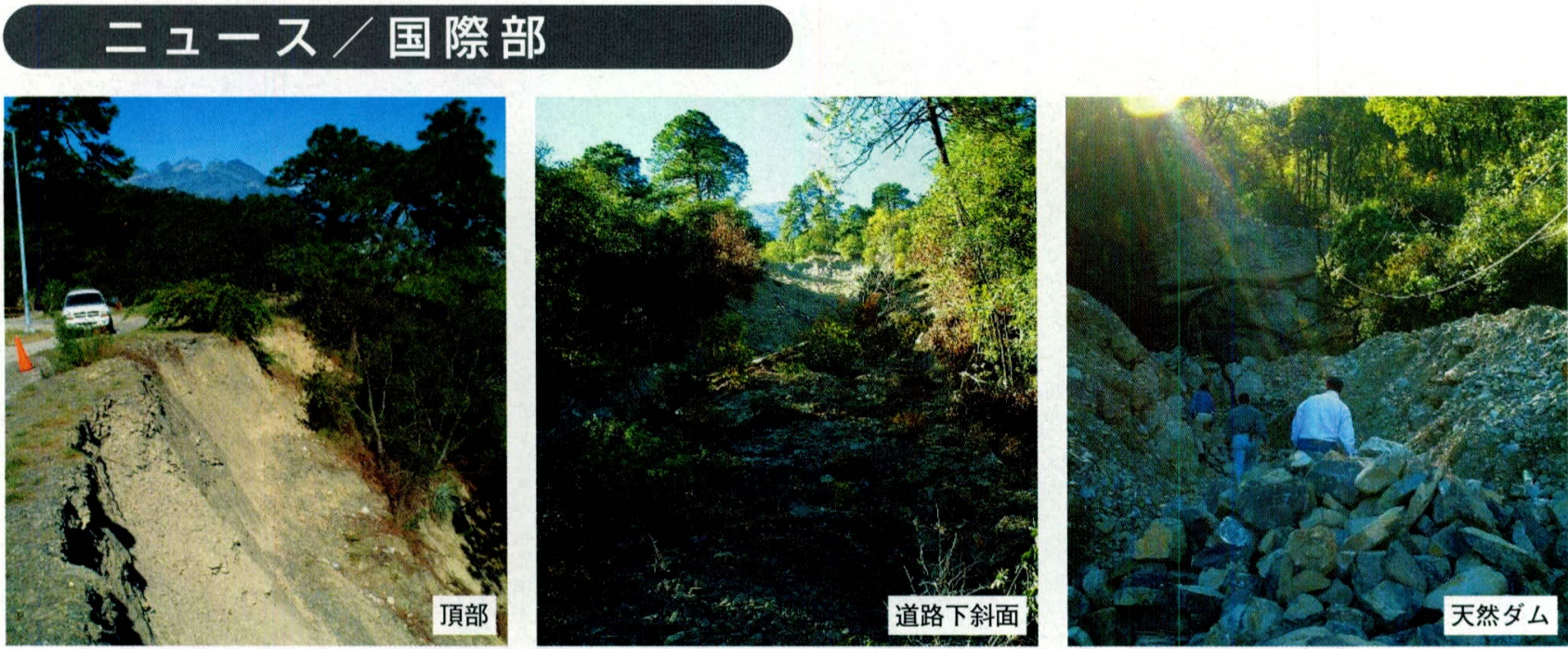

マリポサス渓谷の道路盛土斜面崩壊と溪床に形成された天然ダム。

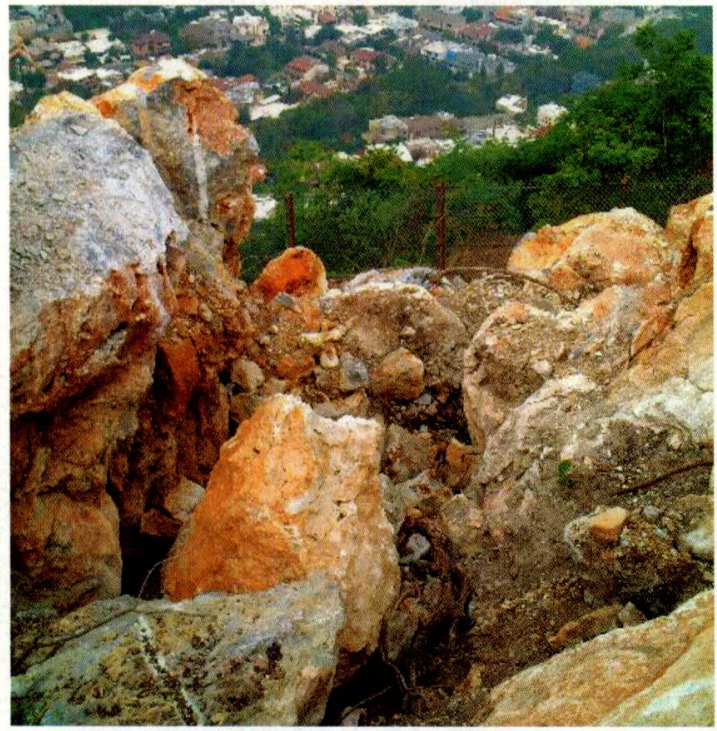

セロ・デラ・コロナ地区における台地状斜面上角磁岩の斜面崩壊

$$
\text { シリーズ }
$$

口火砕流台地で発生した 銅山川地すべりのすべり面

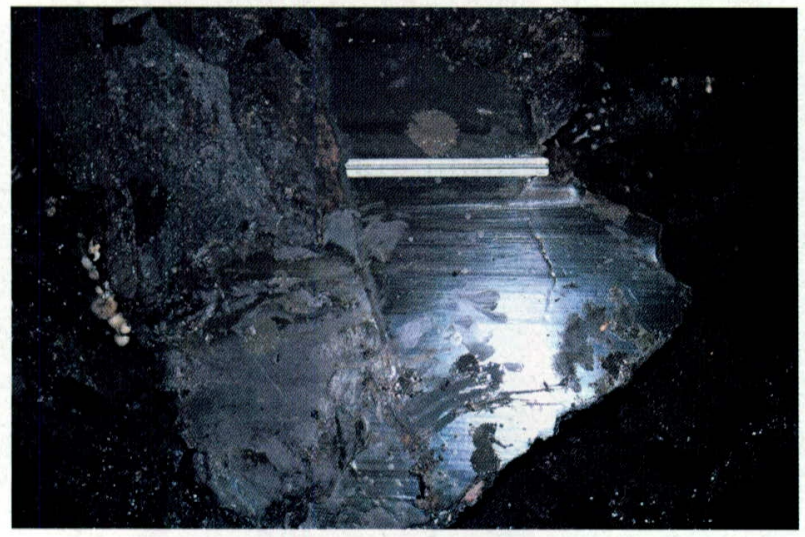

脱出坑のすべり面（上盤を裏返しに撮影）

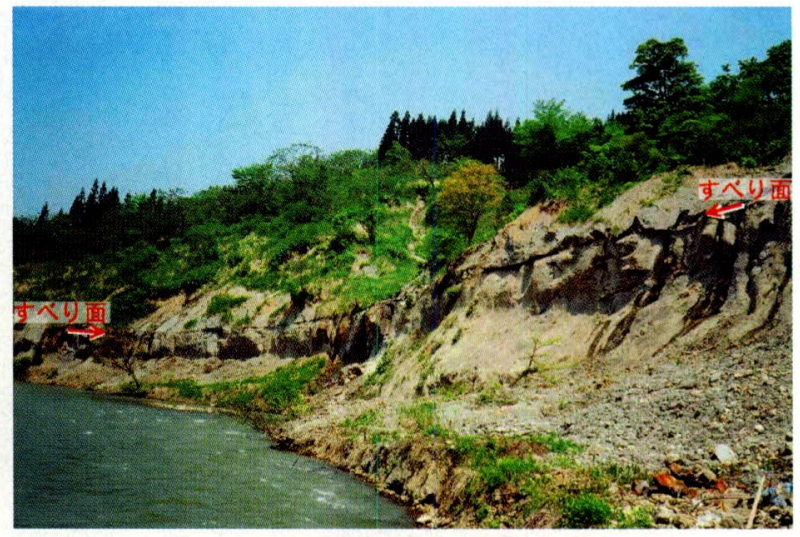

末端部で観察されるすべり面

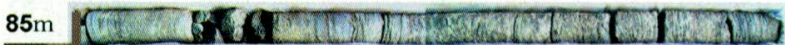

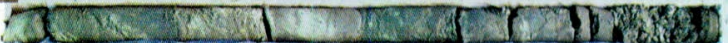

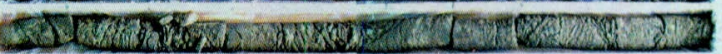

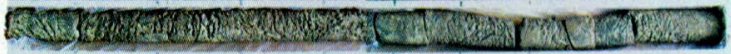

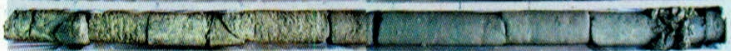
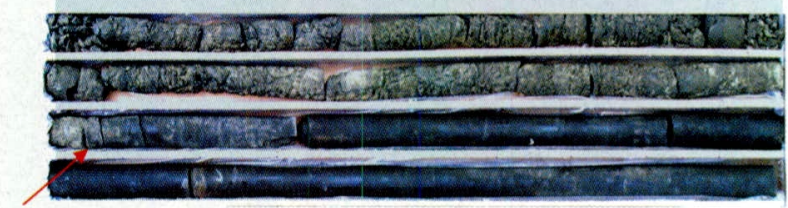

すべり面(92.05m) 